\title{
EXPLORING RELATIONSHIP BETWEEN MARKET ORIENTATION AND PERFORMANCE IN START-UPS COMPANIES IN GHANA
}

\section{ARMAH-BEMPONG ERIC ${ }^{1}$ \& KOFI OWIREDU GHORMAN ${ }^{2}$}

${ }^{1}$ Lecturer, Perez University College, Winneba \& PhD Candidate, Open University of Malaysia, Lumpur, Malaysia

${ }^{2}$ Lecturer, Sunyani Technical University, Ghana

\begin{abstract}
The purpose of the study was to explore the application of market orientation among start-up companies in relationship with start-up success. The study reviewed the market orientation literature with special emphasis on developing economy contexts while also incorporating the start-up literature on small and medium scale business perspective. The study uses both the qualitative and quantitative approach to understand detailed insights. The case use was private broadcasting company. The researcher interviewed the operations managers, sales/ customers' service managers and brand research managers. The study found that there is a link between service quality and market orientation of firms as has already established by Esteban et al (2001) however, most companies have not taken full advantage of the link, that MO is having a full impact on firms business performance and hence the study can confirm the initial proposition that MO has an impact on the performance of start-ups.

On the issue of employee satisfaction the company employees seem somehow satisfied because they are involved in the decision making strategies to improve performance, but it was found out that other factors such as rewards and promotion have a role to play in employee satisfaction.

The study recommends that start-up firms should engage in MO activities as it is seen to have a positive relation with performance.

KEY WORDS: Marketing Orientation, Start-Ups \& Performance
\end{abstract}

Received: Jul 06, 2017; Accepted: Jul 26, 2017; Published: Aug 16, 2017; Paper Id.: IJSMMRDAUG20176

\section{INTRODUCTION}

Most markets are moving towards a more market-oriented approach because customers have become more knowledgeable and require more variety and better quality (Perry and Shao, 2002). To compete, businesses need to be more sensitive to their customer's needs otherwise they will lose sales to their rivals. A marketing oriented approach means a business anticipates finds and responds to what customers want. The decisions taken are based around information about customers' needs and wants, rather than what the business thinks is right for the customer (Wilson and Pelham, 1996). Most successful businesses take a market-oriented approach.

Market orientation perspectives include the decision-making perspective (Shapiro, 1988), market intelligence perspective (Kohli and Jaworski, 1990), culturally based behavioral perspective (Narver and Slater, 1990), strategic perspective (Ruekert, 1992) and customer orientation perspective (Deshpande et al., 1993). The two most prominent conceptualizations of market orientation are those given by Kohli and Jaworski (1990) and Narver and Slater (1990). While Kohli and Jaworski (1990) consider market orientation as the implementation of the 
marketing concept, while Narver and Slater (1990) consider it as an organizational culture.

Kohli and Jaworski (1990) defined market orientation as "the organization-wide generation of market intelligence, dissemination of the intelligence across departments and organization-wide responsiveness to it". According to them, the marketing concept is a business philosophy, whereas the term market orientation refers to the actual implementation of the marketing concept. They added that "a market orientation appears to provide a unifying focus for the efforts and projects of individuals and departments within the organization."

To be market orientated implies that the firm embraces a strategy to obtain and use information about the environment and to disseminate this information throughout the firm. As mentioned before, the foundation of the marketing discipline is the "marketing concept" and the origin of this concept is in the focus by the firm on the customer and their needs (Drucker 1954; Levitt 1960).

A market-oriented firm is one which successfully applies the marketing concept (Kohli \& Jaworski, 1990; Pitt et al., 1996; Caruana et al., 1999). According to Blankson and Cheng (2005), the marketing concept holds that the key to organizational success is through the determination and satisfaction of the needs, wants and aspirations of target markets. They noted that these must be pursued more effectively and efficiently than that of competitors and with the intention of achieving profitability and or satisfying objectives. From the strategic marketing literature, market orientation involves the use of superior organizational skills in understanding and satisfying customers (Day, 1990). In essence, market orientation is derived from the application of marketing concept and it requires firms to monitor rapidly changing customer needs and wants, determine the impact of these changes on customer satisfaction, increase the rate of product innovation, and implement strategies that build the firms' competitive advantages.

Studying market orientation in Ghana among Ghanaian SMEs, Mahmoud (2011) found that it is in this sector that firms need to be more customer focus, monitor competitive trends, and respond appropriately to market intelligence in order to survive given evidence of their financial, technical and other constraints. Following an adoption of two popular scales in the literature, (Mahmoud, 2011) investigated the market orientation-performance link among Ghanaian SMEs using a survey to collect data on 191 firms. Results show that the development of market orientation in this sector rests more on the attitude of owners/ managers and, more importantly, the repeatedly reported performance implication of market orientation does not elude Ghanaian SMEs. More specifically, market orientation leads to superior performance under ceaseless competitive conditions.

\section{RESEARCH OBJECTIVES}

The general objective of the proposed research is to contribute to the body of knowledge by exploring relationship between market orientation and performance in start-ups.

To achieve the general objective, the research will be aimed at addressing the following specific objectives:

- $\quad$ To determine the key market orientation variables in start-ups

- To determine the impact of these variables on start-up performance

- To ascertain the level of market orientation of start-up companies in Ghana.

- To determine the relationship between market orientation and business performance of start-up companies in the Market. 


\section{LITERATURE REVIEW}

The marketing concept, particularly its implementation aspect, has received a lot of attention from marketing and management researchers over the last few decades (Turner and Spencer, 1997; Kotler and Armstrong, 2010). The term "market orientation" was used in the literature to refer to the implementation of the marketing concept (e.g. Shapiro, 1988; Narver and Slater, 1990; Kohli and Jaworski, 1990). Also, Market orientation theorists such as Kohli and Jaworski (1990), Narver and Slater (1990), Ruekert (1992), Gainer and Pandanyi (2005), Carr and Lopez (2007) have posited that market orientation traces its origins from the marketing concept and has consequences to overall business strategy. The implementation of the market concept is so crucial because it is the means by which firms' behaviour are studied and understood. Market orientation has been found to facilitate firms' ability to anticipate, react to and take advantage of environmental changes, which leads to superior performance of a firm (Shoham et al., 2005).

Moreover, the marketing concept is concerned with customer-orientation, competition-orientation, innovation and profit as an inducement for creating satisfied customers (Narver and Slater, 1994; Hunt and Morgan, 1995). While productcentered organizations are concerned with developing products and services that are then marketed and hopefully sold, market oriented companies aim at developing products and services that meet the needs and expectations of their customers (Grönroos, 2006). Thus, being market-oriented will require that an organization adapts its business behaviour to be consistent with the marketing concept. This means market orientation involves creation of customer value. According to Chen and Quester (2009), the link between market orientation and customer value has introduced two arguments: customer value is a theory emphasizing the implementation of customer-centric thinking in marketing; and customer value is regarded as the foundation for achieving a positive business performance (Alhakimi and Baharun, 2009).

The attention of researchers to the study of market orientation, over the last few decades supports the acknowledgement of the important role of market orientation in achieving a sustainable competitive advantage (Castro et al., 2005). The crucial role of market orientation was acknowledged by Deshpande and Webster (1989), who associated the idea of market orientation with the organizational culture. They viewed market orientation as a behavioural process that emerges through specific organizational activities (Kohli and Jaworski, 1990), and as organizational culture that produces the necessary behaviours to create superior value for customers (Narver and Slater, 1990). Furthermore, Hurley and Hult (1998) found market orientation as composing of a set of behaviours or an aspect of culture. Other studies viewed market orientation as an innovation (Rogers, 1983; Liu, 1995; Fritz, 1996).

Major issues that creates a gap in the market orientation literature is the lack of systematic effort to develop valid measures of market orientation (Kaynak and Kara, 2004); and the inconsistencies in the outcome of the market orientation studies in developing countries (Malik and Naeem, 2009; Qu and Ennew, 2009). This paper aims at building a synthesis model of market orientation constructs for companies in the Stock Exchange Market using evidence from Ghana. This is significant because previous scales (Shapiro, 1988; Kohli and Jaworski 1990; Narver and Slater 1990; Reukert, 1992; Deshponde et al., 1993; Becker and Homburg, 1999) have measured the market orientation construct from different perspectives. Thus, since the development of these different perspectives, researchers have tried to adopt one perspective or the other in their study of market orientation (Liu, 1995; Fritz, 1996; Kaynak and Kara, 2004; Malik and Naeem, 2009; Qu and Ennew, 2009). The use of an integrated approached to the study of market orientation is under researched. The few studies that have tried to adopt a synthesis model have done so in different country context a different industry context 
(Zebal, 2003; Alhakimi and Baharun, 2009). Therefore, it may be reasoned that the integration of the market orientation perspectives; and the modification of some previous relevant scales will help in achieving a better measurement and understanding of the market orientation construct in Ghana (Osuagwu, 2006). Also, the use of companies from the Stock Exchange Market should address the inconsistencies that might result from different industry context.

The terms "market orientation" and "marketing orientation" can be confusing. Shapiro (1988) claims that "market orientation" is a construct that is not exclusively the concern of marketing, but rather a variety of departments participating in generating and disseminating market intelligence and taking actions as a response.

Kohli and Jaworski (1990) conclude the term "marketing orientation" to be misleading as it is the responsibility of all departments. They contend that "market orientation" focuses attention on markets, which includes not only customers but also forces affecting them. It is constructed of three elements:

Intelligence generation;

- Intelligence dissemination; and

- Responsiveness to the generated and disseminated intelligence.

Jaworski and Kohli (1993) later contended that there are three sets of antecedents related to market orientation:

- $\quad$ Top management - emphasis on market focus and risk aversion;

- $\quad$ interdepartmental factors, e.g. conflicts between departments; and

- Connectedness and organizational systems, e.g. the form of an organization's structure and reward systems.

It is pointed out by marketing scholars that market orientation can be traced back to the 1950s where customer research guided production and organizations view customer satisfaction as a reason for their existence and operations. Levitt (1960) supported this argument, when he asserted that customers' need must be the firm's core business purpose. Other authors subsequently extended the core of this idea into what eventually came to be known as the marketing concept. Since then numerous academics and practitioners have argued that the customer oriented business philosophy be made an essential part of everyday management practice (Webster, 1988 and Shapiro, 1988). Terms such as "Market oriented", "Customer oriented", "Customer focused", "Market driven" and "Customer centric" are used interchangeably in the literature (Deshpande1999).

Esteban et al, 2001 did a profound review of the literature and reveals varied definitions of the marketing concept. In Felton, 1959 the marketing concept was defined as a corporate state of mind that insists on the integration and coordination of all the marketing functions, which, in turn, intermingle with all the other corporate functions, for the basic purpose in order to maximize profits in the long run. In contrast, other authors opt for wider framework and define the concept as a philosophy based on the whole company accepting customer orientation, profit orientation and the realization of the important role played by marketing when attempting to translate market necessities to the rest of the enterprise developments. It is argued that if the marketing concept means that the marketing department has to play a leading role so that the enterprise operations in its environment are successful, then, this orientation implies that special emphasis should be laid on the following items, even though variations of this concept can be found in other works: 
Customer orientation, that is, the knowledge of what is wanted or needed before the marketing process begins.

- Profitability of the marketing operations through satisfying customers' needs.

- An organizational structure in which all marketing activities have been developed by the marketing department, whose director has the same position in the structure as production and financing directors.

Whereas the concept of marketing is considered as a philosophy in itself, included in the organizational structure, marketing orientation is understood as the acceptance of the marketing concept. In this sense, the marketing concept constitutes a separate way of thinking about the organization, its products and its customers. In short, marketing concept is a set of attitudes towards the market. Marketing orientation on the other hand dedicates itself to providing the steps needed to develop this philosophy in a company. Hunt and Morgan (1995) and Esteban et al (2001) pointed that as opposed to the marketing concept and its implantation as marketing orientation, market orientation does not only make reference to actual but also to potential customers. They went further to indicate that market orientation takes into account the influence of competitors and incorporates inter-functional coordination. In this way, marketing ceases to be a function to become a way of doing business. There seems to be total agreement, when defining market orientation according to these five dimensions: consumer orientation, competitor orientation, supplier-dealer orientation, environmental orientation and inter-functional coordination.

Nevertheless, it still needs to be clarified whether market orientation implies a specific kind of behaviour or attitude. Some Authors have dealt with this problem: Deshpande and Webster (1989) described market orientation as a type of business culture. Following their idea, two approaches to market orientation have been presented and widely adopted. The first distinguishes three components: organization-wide generation of market information about current and future customers needs; dissemination of such information across departments and individuals within the market-oriented firm; and an organization-wide responsiveness to the disseminated information (Jaworski and Kohli, 1993; Kohli and Jaworski, 1990). The second also uses three components, but conceptualizes market orientation differently.

Slater and Narver, (1995), the first component is customer orientation, which reflects the necessary activities for acquiring and dissemination information about customers. The second, a competitor oriented, implies an effort to gather and disseminate information about competitors of the market-oriented firm. The third component, inter-functional coordination, involves "the business's coordinated effort to create superior value for them continuously" (Narver and Slater, 1990). Cadogan and Diamantopoulos (1995) identified many common themes between the two approaches, except for responsiveness, customer and competitors' orientations. Firm performance is central to both approaches; the former also assessed behavioral outcomes: organizational commitment and esprit de corps.

Market orientation differs from the traditional notion of marketing orientation in several ways. Firstly market orientation is no longer a concern of the marketing department, but rather a concern of all functional areas of the organization. Each has the aim of creating superior value for customers. Secondly, and related to the first, an organization that is market oriented does not view the marketing department as being more important than other departments (Shapiro, 1988 and Webster, 1994). All must work together to achieve superior value.

Many definitions of market orientation has been provided by scholars in the field, for example, Deshpande and Webster (1987) defined market orientation as an organizational culture that has shared values and believes in putting the 
customer first in business planning.

Narver and Slater (1990) also viewed market orientation as an organizational culture. However, they went further and argued that market orientated firms' focus not only on customers but also on competitors. Narver and Slater stated that competitor orientation is equally important as customer orientation. They also place emphasis on the importance of interfunctional coordination, achieving unison between all parts of the organization. For Deshpande and Farley (1998), by contrast, market orientation is a set of cross-functional process and activities directed at creating and satisfying customers through continuous needs assessments. They did not emphasis competitor orientation at all.

Another pair of renowned scholars in the field, Kohli and Jaworski (1990), viewed market orientation as the implementation of the marketing concept. They defined and measured market orientation as a set of activities or behaviours related to market intelligence dissemination across functions within an organization, and the action responses based on this intelligence. Kohli and Jaworski emphasized the behavioral aspect of market orientation. They did not suggest that market orientation is an aspect of organizational culture. Other researchers viewed market orientation differently and argued that it is not the implementation of the marketing concept as proposed by Kohli and Jaworski (1990) but rather supplementary to the marketing concept (Hunt and Morgan, 1995). Market orientation comprises the systematic gathering of information on customers and competitors both present and potential, the systematic analysis of the information for the purpose of developing market knowledge, and the systematic use of such knowledge to guide strategy recognition, understanding, creation, selection, implementation and modification (Hunt and Morgan 1995). Their definition focuses on both customers and competitors but does not mention inter-functional coordination.

Market orientation is a set of processes aimed at acquiring information on all important buying influences and spreading information through every department in the organization (Shapiro, 1988). Shapiro (1988) further emphasized that a market oriented company is the one that completely understands its customers. He suggested that in order to be market oriented, collaboration among the various functions in an organization is important.

Like other management concepts, market orientation is a multidisciplinary and complex concept. Mavondo et al. (2005) speculated that market orientation is both exploration and exploitation. Market orientation is exploration because it fosters the organizations continues learning about its customers, competitors, markets, etc. Exploitation refers to the fact that market orientation enables the organization to use the information to its advantage to advance its own welfare. Mavondo et al. (2005: 1241) suggested: "a market orientation is primarily concerned with a relentless pursuance of intelligence pertaining to customers, competitors and internal organizational integration (Narver and Slater, 1990) or about information acquisition, information dissemination and responding to information (Kohli and Jaworski, 1990, Jaworski and Kohli 1993). Mavondo et al. (2005) concluded: “Our findings suggest that a market orientation is an important antecedent to product innovation, process innovation and administrative innovation (p. 1256)". Some literature uses the variable "customer orientation" interchangeably with market orientation, while some differentiate the two (Hammond et al., 2006; Pitt et al., 2007).

Concepts that a multidisciplanary, usually by nature turn to create some confusion in their understanding and application. Market orientation is one such concepts. Therefore, it is significant to discuss market orientation by synthesising the different perspectives to create a complete harmony in understanding and applying the concept. Six different perspectives of market orientation are identified in the literature: five by Lafferty and Hult (2001); and one by 
Helfert et al. (2002) which the study seeks to synthesise to remove any misconceptions in appreciation of the subject matter; and strengthen the investigation of markete orientation and business performance linkage in this study. The six concepts of market orientation are:

- Organizational decision making perspective (Shapiro, 1988)

- Market intelligence perspective (Kohli and Jaworski, 1990)

- Culturally based behavioural perspective (Narver and Slater, 1990)

- The strategic focus perspective (Ruekert, 1992)

- The customer orientation perspective (Deshponde et al., 1993)

- System-based perspective (Becker and Homburg, 1999)

Each perspective proved to be an interesting venue for study and further development of the market orientation concept. Consistent with previous studies (Zebal, 2003; Alhakimi and Baharun, 2009; Helfert et al., 2011), this research, acknowledges the importance of a combination approach to the discussion of market orientation. Thus, market oriented companies should tailor beliefs and actions to be consistent with the six dominant conceptualizations of market orientation. The six sub-sections that follow explore the five different perspective of market orientation in an attempt to synthesise them to meet the research needs of this study.

\section{METHODOLOGY OF THE STUDY}

This paper is based on both primary and secondary data. Primary data were collected through a structured questionnaire which was administered personally to the brand managers of the various companies. Convenient sample technique has been used to interview the brand managers. The target population of this study was brand managers in the media industry. Among various media companies in the metropolis, this study only considered Multi-media as a company and four other media companies which could be considered as the most vibrant among their peers. For conducting this research, 139 customers are selected from the many brand managers and their sales executives of the various companies and out of this 119 of the respondents responses properly, the response rate is 93.3 percent. The questionnaire consists of different questions on what constitute marketing orientation variables and levels of market orientation start-up in some organization, in some instance the questionnaire also tested market orientation and business performance of a company. The questionnaire was developed by using the various objectives in of exploring marketing orientation in start-up businesses and their performance.

But some secondary data have been used in the study. The secondary data used in the study have been collected from related journals, books, newspapers and internet, etc. In this study, some statistical measures would be use to measure the performance of start-up businesses as far as market orientation is concern.

\section{ANALYSIS AND FINDINGS}

This section unfolds results on the first specific research objective. This objective identifies the extent of the key market orientation variables in start-ups and the impact of these variables on start-up performance

Table 4.1shows one-sample descriptive statistics that reveal the key marketing orientation variables and their 
impact on start-up companies. $\mathrm{TMO}=$ Top Management Orientation, IDEFO= Interdepartmental Factors Orientation, $\mathrm{COSO}=$ Connectedness and Organizational Systems.

Table 4.1: One-Sample Statistics

\begin{tabular}{|l|c|c|c|c|}
\hline & $\mathbf{N}$ & Mean & Std. Deviation & Std. Error Mean \\
\hline TMO & 371 & 3.1808 & .78983 & .04101 \\
\hline IDFO & 371 & 3.5065 & .70237 & .03647 \\
\hline COSO & 371 & 3.0793 & .68074 & .03534 \\
\hline
\end{tabular}

Source: Researcher's SPSS Computation

In Table 4.1 are one-sample statistics relating to TMO, IDFO and COSO. Here, the goal is to identify the extent to which TMO, IDFO and COSO are practiced in the firms by comparing the magnitude of their means to the maximum value of 5. Thus the mean of a construct cannot exceed 5. The closer the mean to the maximum value of 5, the higher the extent of practice of TMO, IDFO and COSO in the firms. From the table, IDFO has the highest average score $(\mathrm{M}=3.51$, $\mathrm{SD}=0.70)$, followed by TMO $(\mathrm{M}=3.18, \mathrm{SD}=0.79)$ and $\mathrm{COSO}(\mathrm{M}=3.08, \mathrm{SD}=0.68)$. Generally, the extent of practicing IDFO, TMO and COSO in the firms is quite high. Also, firms seem to practice IDFO at a higher extent relative to TMO and COSO. The following tables help us to be sure of these clues.

Table 4.2: One-Sample Test

\begin{tabular}{|c|c|c|c|c|c|c|}
\hline & \multicolumn{6}{|c|}{ Test Value $=\mathbf{3 . 0}$} \\
\hline & \multirow[t]{2}{*}{$\mathbf{t}$} & \multirow[t]{2}{*}{ df } & \multirow[t]{2}{*}{ p-Value } & \multirow[t]{2}{*}{ Mean Difference } & \multicolumn{2}{|c|}{ 95\% Confidence Interval of the Difference } \\
\hline & & & & & Lower & Upper \\
\hline TMO & 4.410 & 370 & .000 & .18084 & .1002 & 2615 \\
\hline IDFO & 13.889 & 370 & .000 & .50647 & .4348 & 5782 \\
\hline $\mathrm{COSO}$ & 2.245 & 370 & .025 & .07933 & .0098 & 1488 \\
\hline
\end{tabular}

Source: Researcher's SPSS Computation

Table 4.2 shows the significance test associated with Table 4.1. In this table, we are trying to know if the extent of practicing TMO, IDFO and COSO is higher than average. In this study, the average of the scale used is 3 , which is the test score in Table 4.2. So we would want to know if the extent of practicing TMO, IDFO and COSOO is above this average. This test is done at 5\% significance level. From the table, the extent of practicing each element of the service triangle model is significantly above average $(\mathrm{p}<.05)$, though that of IDFO $(\mathrm{t}=14.89, \mathrm{p}=.000)$ is higher than those of TMO $(\mathrm{t}=$ $4.41, \mathrm{p}=.000)$ and $\operatorname{COSO}(\mathrm{t}=2.25, \mathrm{p}=.025)$. Statistically, there is ample evidence that the firms practice IDFO, TMO and COSO at an extent higher than average. In the next session, we would investigate if the extent of practicing IDFO is significantly different from that of TMO and COSO. This is done using one-way Analysis of Variance.

Table 4.3: ANOVA

\begin{tabular}{|l|c|c|c|c|c|}
\hline & Sum of Squares & df & Mean Square & F & P-Value \\
\hline Between Groups & 36.951 & 2 & 18.475 & 35.067 & .000 \\
\hline Within Groups & 584.807 & 1110 & .527 & & \\
\hline Total & 621.758 & 1112 & & & \\
\hline
\end{tabular}

Source: Researcher's SPSS Computation

Table 4.3 shows the ANOVA test associated with Table 4.2 the null hypothesis being tested is that firms practice TMO, IDFO and COSO at the same extent. This test is done at 5\% significance level. From the table, the test is significant, $\mathrm{F}(2,1110)=18.48, \mathrm{p}<.05$. This means that the null hypothesis is not confirmed. Thus the firms practice one or more of TMO, IDFO and COSO at a higher extent. We would now use a multiple comparison test to identify which of TMO, IDFO 
and COSO is much more practiced by the firms. But since the homogeneity of variances assumption is not satisfied, there is the need to use a multiple comparison test that addresses this problem. Moreover, there is the need to identify if the data is in a good condition to use this alternative multiple comparison test.

Table 4.4: Robust Tests of Equality of Means

\begin{tabular}{|l|c|c|c|c|}
\hline & Statistic $^{\mathbf{a}}$ & df1 & df2 & P-Value \\
\hline Welch & 37.729 & 2 & 737.222 & .000 \\
\hline Brown-Forsythe & 35.067 & 2 & 1090.933 & .000 \\
\hline
\end{tabular}

Table 4.4 shows results of two tests that are used to justify the use of the alterative multiple comparison test. We expect these tests to have p-values smaller than $5 \%$ so to justify the use of the alternative multiple comparison test. Fortunately, both tests (i.e. Welch and Brown-Forsythe) are significant at 5\% significance level. This justifies the use of the alternative multiple comparison test, which the Tamhane's multiple test. Table 4.5 shows results of this test.

Table 4.5: Tamhane's Multiple Comparisons

\begin{tabular}{|c|c|c|c|c|c|c|}
\hline \multirow{2}{*}{ (I) Group } & \multirow{2}{*}{ (J) Group } & \multirow{2}{*}{$\begin{array}{c}\text { Mean Difference } \\
\text { (I-J) }\end{array}$} & \multirow{2}{*}{ Std. Error } & \multirow{2}{*}{ P-Value } & \multicolumn{2}{|c|}{$95 \%$ Confidence Interval } \\
\hline & & & & & Lower Bound & Upper Bound \\
\hline \multirow{2}{*}{ TMO } & IDFO & $-.32563^{*}$ & .05487 & .000 & -.4570 & -.1943 \\
\hline & $\mathrm{COSO}$ & .10151 & .05413 & .173 & -.0280 & .2311 \\
\hline \multirow{2}{*}{ IDFO } & TMO & $.32563^{*}$ & .05487 & .000 & .1943 & .4570 \\
\hline & $\mathrm{COSO}$ & $.42714^{*}$ & .05078 & .000 & .3056 & .5487 \\
\hline \multirow{2}{*}{ COSO } & TMO & -.10151 & .05413 & .173 & -.2311 & .0280 \\
\hline & IDFO & $-.42714^{*}$ & .05078 & .000 & -.5487 & -.3056 \\
\hline
\end{tabular}

Table 4.5 shows results of the Tamhane's multiple comparison tests. With this test, we want to identify details in the difference seen in Table 4.6. From the table, the extent of practicing IDFO by the firms is significantly higher than that of TMO ( $\mathrm{p}=.000)$ and COSO ( $\mathrm{p}=.000)$. The extent of practicing TMO by the firms is however not significantly higher than that of $\operatorname{COSO}(\mathrm{p}=.173)$. There is therefore a higher tendency that start-up firms in the marketing sector give priority to IDFO relative to TMO and COSO, but they practice TMO and COSO at almost the same extent. Though results so far are enlightening, there is the need to see how IDFO, TMO and COSO are correlated. This is analyzed in the next section

Table 4.6: Correlation Between TMO \& IDFO

\begin{tabular}{|l|l|c|c|}
\hline \multicolumn{2}{|c|}{} & TMO & IDFO \\
\hline \multirow{3}{*}{ TMO } & Pearson Correlation & 1 & $.777^{* *}$ \\
\cline { 2 - 4 } & P-value (2-tailed) & & .000 \\
\cline { 2 - 4 } & $\mathrm{N}$ & 371 & 371 \\
\hline \multirow{3}{*}{ IDFO } & Pearson Correlation & $.777^{* *}$ & 1 \\
\cline { 2 - 4 } & P-value (2-tailed) & .000 & \\
\cline { 2 - 4 } & $\mathrm{N}$ & 371 & 371 \\
\hline \multirow{2}{*}{$\begin{array}{l}* * . \\
\text { tailed). Correlation is significant at the 0.05 level (2- }\end{array}$}
\end{tabular}

Table 4.6 shows the relationship between TMO and IDFO, where IDFO serves as the dependent variable in this relationship. We would want to know if IDFO and TMO are correlated at 5\% significance level. From the table, there is a strong positive correlation between TMO and IDFO, $\mathrm{r}(371)=.777, \mathrm{p}<.05$. This means that top management orientation is enhanced when interdepartmental factors orientation is enhanced. Moreover, the rate of change caused by TMO in IDFO is high. In the next table, the relationship between TMO and COSO is examined. 
Table 4.7: Correlation Between TMO \& COSO

\begin{tabular}{|c|l|c|c|}
\hline \multicolumn{2}{|c|}{} & TMO & COSO \\
\hline \multirow{3}{*}{ TMO } & Pearson Correlation & 1 & $.725^{* *}$ \\
\cline { 2 - 4 } & P-value (2-tailed) & & .000 \\
\cline { 2 - 4 } & $\mathrm{N}$ & 371 & 371 \\
\hline \multirow{3}{*}{ COSO } & Pearson Correlation & $.725^{* *}$ & 1 \\
\cline { 2 - 4 } & P-value (2-tailed) & .000 & \\
\cline { 2 - 4 } & $\mathrm{N}$ & 371 & 371 \\
\hline
\end{tabular}

Table 4.7 shows the correlation between TMO and COSO. Here, COSO serves as the dependent variable. We would want to see if an upward change in TMO yields a positive change in COSO. This is done at 5\% significance level. From the table, there is a strong positive relationship between the two variables, $r(371)=.725, p<.05$. This means that increasing the effectiveness of top management marketing orientation (TMO) causes a positive change in connectedness and organizational system marketing orientation (COSO) among start-up service firms in Ghana. In Table 4.8, the relationship between IDFO and COSO is examined.

Table 4.8: Correlation Between COSO \& IDFO

\begin{tabular}{|l|l|c|c|}
\hline \multicolumn{2}{|l|}{} & COSO & IDFO \\
\hline \multirow{3}{*}{ COSO } & Pearson Correlation & 1 & $.631^{* *}$ \\
\cline { 2 - 4 } & P-value (2-tailed) & & .000 \\
\cline { 2 - 4 } & $\mathrm{N}$ & 371 & 371 \\
\hline \multirow{3}{*}{ IDFO } & Pearson Correlation & $.631^{* *}$ & 1 \\
\cline { 2 - 4 } & P-value (2-tailed) & .000 & \\
\cline { 2 - 4 } & $\mathrm{N}$ & 371 & 371 \\
\hline \multirow{2}{*}{$\begin{array}{l}\text { **. Correlation is significant at the } 0.05 \text { level } \\
\text { (2-tailed). }\end{array}$} \\
\hline
\end{tabular}

Table 4.8 shows the relationship between interactive marketing and external marketing. Here, COSO serves as the dependent variable. From the table, there is a strong positive relationship between IDFO and COSO, r $(371)=.631, \mathrm{p}<.05$. This means that the effectiveness of interdepartmental marketing orientation improves as firms enhance their connectedness and organizational system marketing orientation. Relative to the previous relationships however, the relationship between IDFO and COSO is less strong. This is possibly because IDFO is a dependent variable on TMO, so could no strongly influence COSO as TMO does.

Since both IDFO and COSO are dependent on TMO, it is important to examine their relationship if the effect of TMO is controlled for. This test is done in Table 5.9.

Table 4.9: Partial Correlation Between IDFO \& COSO

\begin{tabular}{|l|l|l|c|c|}
\hline \multicolumn{2}{|c|}{ Control Variables } & IDFO & COSO \\
\hline \multirow{4}{*}{ TMO } & \multirow{3}{*}{ IDFO } & Correlation & 1.000 & .157 \\
\cline { 3 - 5 } & & Significance (2-tailed) &. & .002 \\
\cline { 3 - 5 } & \multirow{2}{*}{ df } & Correlation & 0 & 368 \\
\cline { 3 - 5 } & \multirow{2}{*}{ COSO } & .157 & 1.000 \\
\cline { 3 - 5 } & & Significance (2-tailed) & .002 &. \\
\cline { 3 - 5 } & df & 368 & 0 \\
\hline
\end{tabular}

Source: Researcher's SPSS Computation

It is evident that IDFO and COSO are dependent on TMO. Hence there is the need to control for the effect of 
TMO in their relationship. It is only after TMO is controlled for that we can see the real effect of IDFO on COSO. From Table 4.9, both the correlation coefficient and p-value of the relationship between IDFO and COSO reduce when the effect of TMO is controlled for. Thus the correlation between them reduces from a strong one (.631) to a very weak one (.157) when the effect of TMO is controlled for. Though their relationship is still significant, it is evident that a greater part (i.e. 474) of the influence made by IDFO on COSO comes from TMO. So IDFO is less effective on COSO without TMO. In the next session of the analysis, ordinary least squares regression (stepwise method) would be used to model the relationship between TMO, IDFO and COSO.

\section{Levels of Market Orientation of Start-Ups and Business Performance}

In this section, results on the third research objective are presented. The goal in this section is to find out the levels of marketing orientation and start-up firms. (I.e. MC, IMI and RCA) is extended to start-up companies performance among service firms in Ghana. Table 5.2 shows the correlation matrix among company performance $(\mathrm{CP})$, MC= Marketing Concept, IMI= Implementation Issues and RCA= Required Conditions Antecedents.

Table 4.2.1: Correlations Matrix of RCA, IMI, MC \& CP

\begin{tabular}{|c|c|c|c|c|c|}
\hline & & RCA & IMI & MC & $\begin{array}{c}\text { Company } \\
\text { Performance }\end{array}$ \\
\hline \multirow{3}{*}{$\mathrm{RCA}$} & Pearson Correlation & 1 & $.631^{* *}$ & $.725^{* *}$ & $.698^{* *}$ \\
\hline & P-value (2-tailed) & & .000 & .000 & .000 \\
\hline & $\mathrm{N}$ & 371 & 371 & 371 & 371 \\
\hline \multirow{3}{*}{ IMI } & Pearson Correlation & $.631^{* *}$ & 1 & $.777^{* *}$ & $.695^{* *}$ \\
\hline & P-value (2-tailed) & .000 & & .000 & .000 \\
\hline & $\mathrm{N}$ & 371 & 371 & 371 & 371 \\
\hline \multirow{3}{*}{$\mathrm{MC}$} & Pearson Correlation & $.725^{* * *}$ & $.777^{* * *}$ & 1 & $.678^{* *}$ \\
\hline & P-value (2-tailed) & .000 & .000 & & .000 \\
\hline & $\mathrm{N}$ & 371 & 371 & 371 & 371 \\
\hline \multirow{3}{*}{ Company Performance } & Pearson Correlation & $.698^{* *}$ & $.695^{* *}$ & $.678^{* *}$ & 1 \\
\hline & P-value (2-tailed) & .000 & .000 & .000 & \\
\hline & $\mathrm{N}$ & 371 & 371 & 371 & 371 \\
\hline
\end{tabular}

Table 4.32 shows the correlation matrix among MC, IMI, RCA and Company Performance (CP). Generally, Company performance is strongly positively correlated to MC $(\mathrm{r}=.678, \mathrm{p}<.05)$, IMI $(\mathrm{r}=.777,<.05)$ and $\mathrm{RCA}(\mathrm{r}=.698, \mathrm{p}$ $<.05)$ at $5 \%$ significance level. The strongest relationship is seen between RCA and company performance, $r(371)=.698, p$ $=.000$. Since MC largely influences IMI, RCA and CP, there is the need to control for its effect in the relationship between $\mathrm{CP}$ and IMI, and the relationship between $\mathrm{CP}$ and RCA.

Table 4.2.2: Partial Correlation between IMI and Company Performances

\begin{tabular}{|l|l|l|c|c|}
\hline \multicolumn{3}{|c|}{ Control Variables } & IMI & Company Performance \\
\hline \multirow{4}{*}{ MC } & \multirow{3}{*}{ IMI } & Correlation & 1.000 & .364 \\
\cline { 3 - 5 } & & Significance (2-tailed) &. & .000 \\
\cline { 3 - 5 } & \multirow{3}{*}{ Company Performance } & Correlation & .364 & 368 \\
\cline { 3 - 5 } & & Significance (2-tailed) & .000 & 1.000 \\
\cline { 3 - 5 } & & df & 368 &. \\
\hline
\end{tabular}

Source: Researcher's SPSS Computation 
Table 4.2.2 shows the partial correlation between IMI and company performance, where MC is controlled for. In the table, the relationship between IMI and company performance reduces from.695 to.364 when MC is controlled for. Thus the strength of the relationship between IMI and CP falls to a weak status by.334. This means that a large influence is made by MC on IMI in influencing CP. Since the strength of the relationship is still significant even after MC is controlled for, it suggests that the effect of IMI on CP does not only come from MC. In essence, practicing MC does not mean that IMI is not needed to shape company performance.

Table 4.2.3: Partial Correlation between CP and RCA

\begin{tabular}{|l|l|l|c|c|}
\hline \multicolumn{2}{|c|}{ Control Variables } & \multicolumn{1}{c|}{$\begin{array}{c}\text { Company } \\
\text { Performance }\end{array}$} & RCA \\
\hline \multirow{4}{*}{ Company Performance } & Correlation & 1.000 & .408 \\
\cline { 3 - 5 } & \multirow{3}{*}{ MC } & Significance (2-tailed) &. & .000 \\
\cline { 3 - 5 } & \multirow{2}{*}{ RCA } & df & 0 & 368 \\
\cline { 3 - 5 } & & Correlation & .408 & 1.000 \\
\cline { 3 - 5 } & Significance (2-tailed) & .000 &. \\
\cline { 3 - 5 } & df & 368 & 0 \\
\hline
\end{tabular}

Source: Researcher's SPSS Computation

Table 4.2.3 shows the partial correlation between RCA and company performance, where MC is the controlled variable. In the table, the relationship between RCA and company performance reduces from.698 to.408. Thus the strength of the relationship between RCA and CP falls to a weak status by.290. This means that quite a large influence is made by MC on RCA in influencing company performance. Yet since the strength of the relationship is still significant even after $\mathrm{MC}$ is controlled for, it suggests that the effect of RCA on $\mathrm{CP}$ does not only come from MC. By implication, practicing MC does not mean that RCA is not needed to shape company performance.

Since the relationship between CP and MC, IMI and RCA is strong in Table 4.2.3, it is possible that CP can be expressed as a linear combination of MC, IMI and RCA. The following tables come with results that confirm this assertion.

Table 4.2.4: Model Summary - Prediction of CP

\begin{tabular}{|c|c|c|c|c|}
\hline Model & R & R Square & Adjusted R Square & Std. Error of the Estimate \\
\hline 1 & $.698^{\mathrm{a}}$ & .488 & .486 & .57312 \\
\hline 2 & $.772^{\mathrm{b}}$ & .596 & .593 & .50990 \\
\hline 3 & $.775^{\mathrm{c}}$ & .600 & .597 & .50775 \\
\hline a. Predictors: (Constant), RCA \\
b. Predictors: (Constant), RCA, IMI \\
c. Predictors: (Constant), RCA, IMI, MC \\
\hline
\end{tabular}

Table 4.2.4 shows the model summary of the prediction of CP by MC, IMI and RCA. In the table, RCA alone accounts for $48.8 \%$ of the variation in CP. In the second model, IMI and RCA account for 59.6\% of the variation in CP. This means that IMI alone accounts for about $10.8 \%$ of the variation in CP. In the third model, MC, RCA and IMI account for $60 \%$ of the variation in $\mathrm{CP}$. In essence, MC alone accounts for about $0.4 \%$ of the variation in CP. Table 5.2.5 indicates if the regression analysis has improved the researcher's ability to examine the relationship between company performance and the three constructs of the Synthesis Marketing Model of Market Orientation

\section{CONCLUSIONS AND RECOMMENDATIONS}

As a reminder, the objective of this study is to determine the key marketing orientation variables in start-up companies in Ghana. This study also seeks to examine if the possible relationship between market orientation and business 
performance of start-up companies. Hence this study assesses the mediating role of the levels of marketing orientation of start-up companies.

As identified in the summary, the three dimensions of the synthesis marketing model of market orientation. (i.e. $\mathrm{TMO}=$ Top Management Orientation, IDFO=Interdepartmental Factors Orientation, and COSO=Connectedness and Organizational Systems) are positively correlated.

Moreover, the synthesis model is positively linked to company performance as determined in the analysis that $\mathrm{MC}=$ Marketing Concept, IMI=Implementation Issues and RCA=Required Conditions Antecedents also have a positive relationship. In this section, conclusions are presented based on findings of the study. The following subsection presents conclusions on the link among the three construct of the synthesis marketing model.

Based on the study's findings, start-up firms would need to enhance the effectiveness of their market orientation to leapfrog their business performance from the perspective of customers' needs and expectations. Since customer satisfaction is an outcome of how well service delivery meets or exceeds the expectations of customers (Angelova \& Zekiri, 2011), start-up firms must consequently orient their internal, external, and interactive marketing processes to customers' service delivery expectations. According to Bitner et al. (1994), being able to do this would enable firms to achieve higher company performance. This argument by Bitner et al. (1994) is also supported by the study's findings which point to a positive effect of each dimension of the synthesis marketing model of market orientation.

For start-up firms to be able to achieve desired performance and organizational value through practices of internal, external and interactive marketing orientation, some specific measures must be taken. These steps are basically strategic activities in the firm's internal, external and interactive marketing orientation (Furseth \& Cuthbertson, 2013). In this section, the goal is to present research recommendations that have a strong bearing with what start-up firms can do within the scope of internal, external and interactive marketing orientation to maximize corporate and customer value both in the short and long terms. In the following subsections, steps are recommended in this respect at two levels: (1) at the levels of market orientation of start-ups and business performance; and (2) the market orientation variables.

\section{REFERENCES}

1. Atuahene-Gima, K. (1995), "An Exploratory Analysis of the Impact of Market Orientation on New Product Performance", Journal of Product Innovation Management, Vol. 12, pp. $275-93$.

2. Baker, T.L., Simpson P.M. and Siguaw, J.A. (1999), "The Impact of Suppliers' Perceptions of Reseller Market Orientation on Key relationship Constructs", Journal of the Academy of Marketing Science, Vol. 27, pp. 50-57.

3. Baker, W. E., and Sinkula, J. M. (1999a). The synergistic effect of market orientation and learning orientation on organizational performance. Journal of the Academy of Marketing Science, 27(4), 411-427.

4. Baker, W. E., and Sinkula, J. M. (1999b). Learning orientation, market orientation, and innovation: Integrating and extending models of organizational performance. Journal of Market Focused Management, 3(4), 295-308.

5. Becker, J., and Homburg, C. (1999). Market-oriented management: A system-based perspective. Journal of Market Focused Management, 4(1), 17-41.

6. Berry, L.L., (1995). Relationship marketing of services - growing interest, emerging perspectives. Journal of the Academy of Marketing Science 23 (4), 236-245. 
7. Berry, L. L., Zeithaml, V. A., and Parasuraman, A. (1990), "five Imperatives for Improving Service Quality", Sloan Manage Rev, 31 (4): $29-38$.

8. Bhuian, S. N., Menguc, B., and Bell, S. J., (2005. Just Entrepreneurial enough: The moderating effect of entrepreneurship on the relationship between market orientation and performance. Journal of Business Research 58, 9-17.

9. Bozic, L., 2006. The effects of market orientation on product innovation. Economic Trends and Economic Policy 107, 46-65.

10. Brown, S. P., and Peterson, R. A. (1993). Antecedents and consequences of salesperson job satisfaction: meta-analysis and assessment of causal effects. Journal of Marketing Research, 30(1), 63-77.

11. Blankson, C. and Cheng, J.M.S. (2005). "Have Small Businesses Adopted the Market Orientation Concept? The Case of Small Businesses in Michigan”, Journal of Business and Industrial Marketing, Vol. 20, No. 6, pp. 317-30.

12. Boyd, B.K., Dess, G.G., Rasheed, A.M. (1993), "Divergence between Archival and Perceptual Measures of the Environment", Academy of Management Review, Vol. 18 No.2, pp.204-23.

13. Brady, M.K., Cronin, J. Jr (2001), "Some New Thoughts on Conceptualizing Perceived Service Quality: A Hierarchical Approach", Journal of Marketing, Vol. 65 pp.34-49.

14. Brittain, J.W., Freeman, J.H. (1980), "Organizational Proliferation and Density-Dependent Selection", in Kemberly, J.R., Miles, R.H. and Associates (Eds), The Organizational Life Cycle, Jossey-Bass, San Francisco, CA, pp.291-338.

15. Cadogan, J. W., Diamantopoulos, A., 1995. Narver and Slater, Kohli and Jaworski and the Market Orientation Construct: Integration and Internationalization. Journal of Strategic Marketing 3, 41-60.

16. Caruanna, A., Pitt, L. and Berthon, P. (1999). "Excellence-market Oriented Link: Some Consequences for Service firms", Journal of Business Research, Vol. 44, pp. 5-15.

17. Cadogan, J.W., Cui, C.C., Morgan, R.E. and Story, V.M. (2006), "Factors facilitating the development of market-oriented behavior: a study of Hong Kong manufacturing exporters”, Industrial Marketing Management, Vol. 35, pp. 634-47.

18. Cadogan, J. W., Sundqvist, S, Salminen, R. T. and Puumalainen, K. (2002) 'Market-oriented behavior: Comparing service with product exporters' European Journal of Marketing; Volume 36 (9)

19. Cadogan, J.W., Diamantopoulos, A. and Pahud de Mortanges, C. (1999), “A measure of export market orientation: scale development and cross-cultural validation”, Journal of International Business Studies, Vol. 30 No. 4, pp. 689-707.

20. Carr, J.C. and Lopez, T.B. (2007). Examining market orientation as both culture and conduct: modeling the relationship between market orientation and employee responses. Journal of Marketing Theory and Practice; 15, (2) 113-123.

21. Caruana, A., Ramaseshan, B., Ewing, M.T., 1998. Do Universities That Are More Market Oriented Perform Better, International Journal of Public Sector Management, 11(1), 55-70.

22. Chang, T.Z. and Chen, S.J. (1998), "Market orientation, service quality and business profitability: a conceptual model and empirical evidence", Journal of Service Marketing, Vol. 12, No. 4, pp. 246-264.

23. Chen Yung-Kun and Chou Chung (2009) Study on Relationship among Internal Customer Orientation, Market Orientation and Organizational Performance of Theme Restaurants, The Journal of International Management Studies, Volume 4

24. Covin, J.G; Slevin, D.P. and Schultz, R.L. (1994). Implementing strategic missions: Effective strategic, structural and tactical choices. Journal of Management Studies, 31 (4), $481-505$.

25. Cronin, J. J. and Taylor, S. A. (1992), “Measuring services quality: a re-examination and extension”, Journal of Marketing, 
July.

26. Chang, T.-Z., Chen, S.-J. (1998), "Market Orientation, Service Quality and Business Profitability: A Conceptual Model and Empirical Evidence", Journal of Services Marketing, Vol. 12 No.4, pp.246-64.

27. Daft, R.L., Steers, R. (1985), Organizations: A Micro/Macro Approach, Scot

28. Dawes, J. (1999). The relationship between subjective and objective company performance measures in market orientation research: Further empirical evidence. Marketing bulletin, 10, 65-75.

29. Day, G. S. (1994). The capabilities of market-driven organizations. Journal of Marketing, 58, 37-52.

30. Day, G. S. (1992). Marketing's contribution to the strategy dialogue. Journal of the Academy of Marketing Science, 20, 323329.

31. Day, G. S., and Wensley, R. (1988). Assessing advantage: A framework for diagnosing competitive superiority. Journal of Marketing, 52, 1-20.

32. De Luca, L.M., Verona, G., Vicari, S., 2010. Market Orientation and R\&D Effectiveness in High-Technology Firms: An Empirical Investigation in the Biotechnology Industry. Journal of Product Innovation Management. 27 (3), $299-320$.

33. Deal, T. and Kennedy, A. (2000). The new corporate cultures: Revitalizing the workplace after downsizing, mergers and reengineering. London: Texere

34. Deng, S. and Dart, J. (1994). Measuring market orientation: a multi-factor, multi-item approach. Journal of Marketing Management, 10: 725-742.

35. Denison, D.R., Haaland, S. and Goelzer, P. (2004). Corporate Culture and Organizational Effectiveness: Is Asia Different From the Rest of the World? Organizational Dynamics, 33(1), 98-109.

36. Denison, D.R. (1990). Coporate Culture and Organizational Effectiveness. New York: Wiley.

37. Denison, D.R. (1984). Bringing Corporate Culture to the Bottom Line. Organizational Dynamics, 13, 5-21.

38. Desphandé, R. (1999). Developing a Market Orientation. Thousand Oaks, CA: Sage Publications.

39. Deshpande, R., Farley, J.U., and Webster, Jr., F.E. (1993). Corporate culture, customer orientation, and innovativeness in Japanese firms. Journal of Marketing, Vol. 57, No. 1, 23 - 27

40. Diamantopoulos A and Hart S (1993), "Linking market orientation and company performance: Preliminary Evidence on Kohli and Jaworski's framework”, Journal of Strategic Marketing, Vol.1 No.2.

41. Dibb, S., and Simkin, L. (2000), "Pre-Empting Implementation Barriers: Foundations, Processes and Actions - The Need for Internal Relationships", Journal of Marketing Management, 16, 483- 503.

42. Doyle, P., and Wong, V., (1998). Marketing and competitive performance: An empirical study. European Journal of Marketing $32(5 / 6), 514-535$.

43. Drucker, P. F. (1954). The Practice of Management. New York: Harper \& Brothers.

44. Drucker, Peter F. 1954. The Practice of Management. New York: Harper and Row Publishers.

45. Homburg, C., Pflesser, C. (2000), "A Multiple-layer Model of Market-oriented Organizational Culture: Measurement Issues and Performance Outcomes", Journal of Marketing Research, Vol. 37 pp.449-62. 
